\title{
Younger and older trust in a crisis situation
}

\begin{abstract}
Purpose: This paper analyzes consumer trust during a financial crisis, studying its antecedents and consequences. The perceptions of older and younger consumers are also compared.

Design/methodology/approach: The theoretical model of trust formation is tested on a random sample of 634 individuals from the three latgest Spanish cities, Madrid, Barcelona and Valencia, in a period of economic crisis. Structural equation models were used to verify the global hypothesized relationships. Additionally the total sample was divided into two groups (younger and older consumers) in order to test the moderating effect of age in the proposed relationships.
\end{abstract}

Findings: In a period of financial crisis, older consumers' trust is protected by an emotional and experiential shield from the effects of negative news in the surrounding environment. In contrast, trust, although important, is not the core variable for the younger segment, whose preferences are the consequence of a broad range of cognitive and emotional variables.

Research limitations/implications: This research was carried out on financial services. Emotional, relational and experience-linked variables acquire greater importance as the individual gets older, in contrast to more cognitive evaluations. The difference between the younger and the older segments is that the cornerstone of older consumers' attitudinal loyalty is trust, whereas for younger people it is positive switching costs or rewards. Further research on the proposed conceptual model across different industries and countries is needed to determine the generalizability and consistency of the findings from this study.

Practical implications: This paper has significant managerial implications. We believe that the best strategy for a bank during a period of crisis is to follow a customer-friendly orientation, as in the case of banks that took a long-term vision to look after their brand image. The study draws banking companies' attention to the importance of using age as a segmentation criterion.

Originality/value: Based on the life-course paradigm, a theoretical model of trust formation is performed. In a period of economic crisis, trust becomes the key variable in determining older consumers' preferences.

\section{Keywords}

Trust, Older consumer, Loyalty, Switching costs, Satisfaction, Brand image

Paper type: Research paper

Article Classification (JEL): M310; G210 


\section{Introduction}

All developed societies are affected by the trend toward population aging. In 2009 , the median population age in EU-27 was 40.7 years and is projected to reach 47.9 years by 2060 . One of the main demographic trends in EU-27 is that life expectancy continues to rise, especially from gains at older ages. But not only are people living longer lives; they may be living longer healthy lives. Populations that are currently the oldest, such as in Germany and Italy, will age rapidly for the next twenty years, then stabilize. Of the $499,703,311$ inhabitants of EU-27 in 2010, $17.4 \%$ were over 64 , whereas in 1990 the percentage was 13.4\% (Eurostat, 2011).

Differences in older and younger consumers' attitudes and behaviors have been well documented in the literature in relation to various factors: media habits, socialization, adoption of technologies, complaining behavior, shopping behavior, general expenditure patterns, and information processing (Reisenwitz et al., 2007; Hill et al., 2008; Moschis and Nguyen, 2008; Estrada et al., 2010, 2014; Ramón-Jerónimo et al., 2013; Amatulli et al., 2015; Villarejo-Ramos et al., 2016; Monferrer et al., 2016). Traditionally, these differences have been justified by biological, psychological and sociorelational changes that occur during the aging process (Carrigan and Szimigin, 1999; Reisenwitz et al, 2007; Lambert-Pandraud and Laurent, 2010). A new approach has been posited recently, the lifecourse paradigm, that represents a major change in how researchers think about and study consumer behavior in later life, because it makes time, context, and process more salient dimensions of theory and analysis (Moschis, 2012; Lee et al, 2012).

The life-course paradigm posits that consumer thoughts and actions should differ according to the life circumstances people collectively experience. These circumstances include factors in the physical or social environment experienced for a relatively long time, known as period effects, such as periods of economic prosperity or crisis (Moschis, 2012). The world crisis that began in 2008, with a particular impact on the financial sector in the most developed countries, has undoubtedly 
affected the attitudes and behaviors of consumers in general and older consumers in particular. The most evident consequence has been the loss of trust in financial institutions as pointed out by the Marketing Science Institute (MSI, 2011). One country that has suffered most from this crisis is Spain, where the banking sector has undergone radical transformation, with the almost complete disappearance of the savings banks that represented $50 \%$ of bank deposits. This situation meant that in June 2012 the European Union approved a financial bailout of a hundred billion Euros for the Spanish banking system. At the microeconomic level, the crisis has had a negative effect on bank credibility and has eroded customers' trust in their banks. Thus the percentage of Spanish citizens who said they had little or no trust in banks went from $61 \%$ in October 2005 , to $65.3 \%$ in December 2008 and to 76.7\% in October 2010 (CIS, 2013). This loss of trust in banks can also be seen in other countries like the United States (Stevenson and Wolfers, 2011). However, although these macroeconomic data demonstrate the effects of the crisis, they do not enable identification of the changes that have occurred in consumer attitudes and behaviors (Deb and Chavali, 2010; Stevenson and Wolfers, 2011).

The loss of trust in the banking industry during the financial crisis appears to have been irregular. A large number of customers remained faithful to their banks despite negative news surrounding some of these firms. Managers of some branches stated that older people are more reluctant to change banks than other age groups. The life-course paradigm offers an integrating perspective that goes beyond the transversal notion of age by providing psychological and biological explanations for the evolution of consumer behavior. Although its application to research in the area of banking is still in its infancy (Monferrer et al. 2016), we believe it could add a more nuanced and enriched dimension to the conclusions of classic consumer behavior models, and provide interesting recommendations for banking industry managers. 
The aim of this paper is to analyze older consumers' trust during a financial crisis, studying its antecedents and consequences, as compared to the behavior of younger consumers. First of all the paper describes the reference model and the conceptual framework for older consumers on which the study is based: customer loyalty model and the life-course paradigm. Then it analyses the consequences of life-course paradigm on customer loyalty behavior during a financial crisis. In this section, the working hypotheses are formulated, comparing the behaviors of older and younger consumers in a period of financial crisis. The proposed hypotheses are tested on a sample of users of Spanish banks, a paradigmatic industry in the financial crisis that began in 2008.

\section{Customer loyalty model}

Figure 1 depicts the customer loyalty model to be tested in this study. This model is based on Dick and Basu (1994), who proposed an integrated conceptual framework of customer loyalty with the conceptualization of loyalty as the key to the relationship between relative attitude toward an entity and patronage behavior. Relative attitude refers to the fact that it is not sufficient for a consumer to have a favorable attitude to a brand; it must also be more intense in relation to other competing brands. Therefore the model differentiates between attitude and behavioral loyalty.

Loyalty can be defined as a deep commitment to repurchase or repeat purchase behavior for a consistently preferred product/ service in the future, which causes repeat purchase of the same brand or set of brands despite situational influences and marketing efforts which have the potential to bring about changes in behavior (Oliver, 1999). The definition in Oliver (1999) is based on attitude-behavior consistency and relative attitude toward an entity (Dick and Basu, 1994). Then, it is important to emphasize that the focus must not be on repeat purchase behavior alone because of the impact of situational factors and social norm which may hide consumers' true relative attitude (Dick and Basu, 1994; Oliver, 1999; Al-Hawari, Ward and Newby, 2009). This paper focuses on relative attitude or attitudinal loyalty. 
Dick and Basu (1994) identify three types of antecedents of customer loyalty: cognitive antecedents, those associated with informational determinants; affective antecedents, those associated with feelings states involving the brand; and conative antecedents, those associated to behavioral dispositions toward the brand.

Satisfaction and trust are two key antecedents to explain customer loyalty (Dick and Basu, 1994; Morgan and Hunt, 1994). El-Manstrly et al. (2011) defines trust as a function of the perceived reliability and integrity of a brand or service provider. Consumer trust implies consumer familiarity and comfort with a service provider that should reduce the consumer's feelings of anxiety. It is inversely related to the provider's opportunistic behaviors and mixes moral considerations (integrity, honesty, benevolence, deontology, ethics, etc) along with calculated judgments such as ability to meet expectations, competence or know how (Aurier and N'Goala, 2010).

Trust is a prevision consumers make on a company's ability to satisfy their expectations in the future (Guenzi, Johnson and Castaldo, 2009; Aurier and N'Goala, 2010). Trust can be based on cognition when individuals are looking for a rational reason to rely on the other party (McAllister, 1995). But trust can also be based on emotion when it involves emotional bonds between individuals. These two dimensions of trust can be linked together. A relationship between two parties may begin with an expression of cognitive trust, and after a while, based on accumulated experience, it may become affective trust (McAllister, 1995).

Consumer trust is a key element for the supplier to be able to maintain long-term relationships (Dick and Basu, 1994; Morgan and Hunt, 1994; Kantsperger and Kunz, 2010; Aurier and N'Goala, 2010). In services industries, like retail banking, trust becomes crucial in many relational exchange situations and reduces anxiety over the service outcome (Dimitriadis, Kouremenos and Kyrezis, 2011). Many studies have found that customer trust determines customer attitudinal loyalty 
(Chaudhuri and Holbrook, 2001; Chiou and Droge, 2006; Rauyruen et al, 2007; Guenzi, Johnson and Castaldo, 2009; Deb and Chavali, 2010; Kantsperger and Kunz, 2010; Aurier and N'Goala, 2010; Dimitriadis, Kouremenos and Kyrezis, 2011; Trif, 2013).

Customer satisfaction is defined as an emotional state arising from a cognitive process that implies a comparison between customer expectations and customer perceptions of service performance, and an emotional evaluation experienced during consumption (Westbrook and Oliver, 1991). Customer satisfaction can be generated by a discrete transaction, in which episodic satisfaction occurs, and by a long-term relationship between a customer and a supplier (Lam et al 2004). Overall satisfaction describes the consumer's cognitive and affective state resulting from a personal consumption experience (Chandrashekaran et al, 2007).

Customer satisfaction is considered a key driver of the long-term relationship between suppliers and buyers (Westbrook and Oliver, 1991). Dick and Basu (1994) identified satisfaction as an affective antecedent of relative attitude (attitude loyalty) toward an entity. Satisfaction is viewed as an emotion distinct from cognitive assessment or attitudes, arising out of direct prior experience, and independent of cognitive mediation. A satisfied customer's affection toward an entity could motivate the customer to patronize the provider again and recommend the entity to other customers (Yu and Dean, 2001; Rauyruen et al, 2007; Trif, 2013). Satisfaction is often perceived as a factor that influences the likelihood of repurchase or reuse of the service provided by a supplier.

The literature holds that customer satisfaction with a supplier is an antecedent of trust in the supplier (Johnson and Grayson, 2005; Kantsperger and Kunz, 2010; Trif, 2013). Satisfaction remains an evaluation of past service experiences, while trust is more concerned with the future service relationship (Aurier and N'Goala, 2010). 
The satisfaction-trust-loyalty sequence is the cornerstone of customer loyalty behavior. But to assume that satisfied customers are also loyal customers ignores the likelihood that customer, social norm and contextual factors moderate and thus alter this relationship (Dagger and David, 2012). A variable that has deserved much attention in recent years is switching costs (a conative antecedent from Dick and Basu (1994) point of view). Switching costs are the costs customers associate with the process of changing from one provider to another (El-Manstrly et al, 2011). The higher the perceived switching costs, the less likelihood there is of changing brand or provider (Fornell, 1992).

Dagger and David (2012) consider that high switching costs make customers feel locked into the relationship. This can wrongly lead the firm to assume that repeat purchasing reflects a loyal and satisfied customer base, when in fact many customers may be less than satisfied but perceive the costs of switching to another firm as being too high (Bell, Auh and Smalley, 2005). Switching costs can lead to spurious loyalty, which is not the best scenario for maintaining loyalty in the long term.

In this regard it is interesting to categorize switching costs based on the underlying nature of the constraint: positive switching costs, those deriving primarily from positive sources of constraint, and negative switching costs, those deriving primarily from negative sources of constraint (Jones et al, 2007; Maicas, Polo and Sesé, 2006).

The key to this distinction is whether or not switching costs derive primarily from creating benefits and value for the customer. Positive switching costs (social and lost benefits costs) create rewards such benefits and value, whereas negative switching costs (such as procedural and economic switching costs), deriving primarily from negative sources of constraint, do not (penalties). The distinction between positive and negative switching costs is critical to understanding the different mechanisms or routes through which different types of switching costs influence relational outcomes such as retention and WOM (Jones et al, 2007). 
Trust and positive switching costs have a significant influence on attitudinal loyalty in bank branch customers in the UK (El-Manstrly et al, 2011). When customers perceive a service provider as trustworthy, they are more likely to develop a positive attitude toward that service provider and in turn a positive buying behavior. De Matos et al. (2009) found that, in the Brazilian banking industry, switching costs are a significant antecedent of loyalty, and that they played a mediating role between satisfaction and loyalty, particularly on attitudinal loyalty.

Positive switching costs involve loyalty rewards that customers have to give up by when their relationship with the service provider ends. The enjoyment of these benefits may lead the customer to recommend the provider to other customers. As a result, a positive relationship between switching costs and the recommend dimension of loyalty may exist (Lam, et al., 2004; ElManstrly et al, 2011; Tong, Wong and Lui, 2012). In fact, switching costs increase as relationships deepen and broaden (Kamakura et al, 2003; Bell, Auh and Smalley, 2005; Aurier and N'Goala, 2010). As regards switching costs in relation to the other variables, satisfaction and trust, Maicas, Polo and Sesé (2006) and El-Manstrly et al (2011) consider that trust reduces the perception of risk and increases the feeling of wanting to remain in the relationship, and so it can be posited that trust promotes positive switching costs. Customers decide to make durable and non-retrievable inputs in the exchange relationship because they trust their providers and can thus overcome the risks associated with higher dependence (Dwyer et al, 1987; Aurier and N'Goala, 2010).

Finally, brand image is considered an important antecedent of satisfaction, trust and loyalty (Fredericks and Salter, 1995; Bigné et al, 2001; Eskildsen et al, 2004; Faullant, Matzler and Füller, 2008). Brand image and beliefs are cognitive antecedents of relative attitude toward an entity (Dick and Basu, 1994). The strength of the association between an attitude object and its evaluation influences the ease of retrieving the attitude from memory. An automatically activated attitude is more likely to guide behavior than one that must be deliberately retrieved. A more favorable and 
intense brand image determines better attitude accessibility and leads to spontaneous perception of satisfaction, positive switching costs and trust in a service company and activates loyal behavior.

Figure 1. Model of effects

\section{The life-course paradigm}

The life-course model is based on the assumption that human life is characterized by passing through a certain sequence of stages, and suggests that relationships exist between life stage, demographic and behavioral characteristics of individuals (Bauer and Auer-Srnka, 2012). In business contexts, the life-course provides a theoretical basis for understanding changes in consumer needs, consumption patterns and family decision making. Traditionally, life-course research has focused on households, but recently scholars have called for an individual life-course perspective in consumer research (Bailey et al, 2010; Bauer and Auer-Srnka, 2012). Early life course models in marketing are categorical models describing the different life stages, but later conceptualizations, in contrast, represent flow models explaining transitions between successive stages.

The life-course approach goes beyond mere classification of life stages and allows identification of the main types of consumers' role trajectories over time (Bauer and Auer-Srnka, 2012). It considers individuals within their specific historical and social context. Few empirical studies in marketing directly relate to the life-course perspective (Moschis et al, 2009; Bailey et al, 2010; BenmoyalBouzaglo and Moschis, 2010).

The life-course paradigm assumes that biological and psychological changes during a person's life and social demands across the life course define typical life events and social roles that serve as turning points and affect a person's life; they create physical, emotional and social demands and circumstances to which people must adapt by changing their thoughts and actions (Moschis, 2012; Lee et al, 2012). Therefore, study of older consumers' attitudes and behaviors must not only take 
into account the biological and psychological effects of aging but also personal events and the surrounding circumstances that condition those habits.

The biological and psychological effects of aging are quite well known. Biological theories of aging attempt to explain changes in cells and tissues that cause development and deterioration of the biological system and its subsystems and susceptibility to disease and mortality. Changes in bodily systems, such as declines in vision and hearing, and the onset of chronic conditions and disease occur at different ages and at different rates of psychological decline (Moschis, 2012; Lee et al, 2012). Aging brings with it changes in the way the senses perceive information from the surrounding environment. In general, the senses become increasingly less sharp and limitations in distinguishing nuances appear. The aging process also brings changes in the ability to concentrate and memorize.

Psychological models focus on changes in cognition, personality and self. Models of cognition have been used in the field of consumer behavior to study the development and change in patterns of information processing and decision making in later life. The processing-resource framework, which conceptualizes age-related differences in cognition - memory, intelligence, problem solving, and reasoning - in terms of deficits in processing resources has been the most frequently used by cognitive development psychologists as well as by consumer researchers (Lambert-Pandraud, et al, 2005; Yoon et al, 2009).

Particularly relevant in this regard is the research by Lambert-Pandraudand Laurent (2010) which established that three specific mechanisms intervene in the formation of preferences in older consumers: nostalgia, declining innovativeness and attachment. The first mechanism is the theory about nostalgia that posits that consumers develop preferences at an early age and maintain them for the rest of their lives (Holbrook and Schindler, 1991; Reisenwitz et al, 2007). Nostalgia is an emotional state in which an individual yearns for an idealized or sanitized version of an earlier time 
period (Stern, 1992). Some works supports the idea that nostalgia can influence the consumer's lifelong preferences in any product associated with a strong affective experience (Holbrook and Schindler, 1996; Schindler and Holbrook, 2003)

The second mechanism is declining innovativeness, an explanation that asserts that younger consumers have a greater propensity to adopt new products (Botwinick, 1978; Reisenwitz et al, 2007). Finally, the third mechanism is the attachment approach that argues that consumers develop affective links over time with objects or brands because of their personal history with and usage of these objects or brands (Price, Arnould and Curasi, 2000; Thomson, Maclnnis and Park, 2005).

Together with personal events, the life-course paradigm highlights the importance of life circumstances. Consumer thoughts and actions also should differ according to the life circumstances people collectively experience. These circumstances include factors in the physical or social environment experienced for a relatively long time, known as period effects, such as periods of financial crisis; they also include cohort effects, which refer to influences shared by people growing up in a particular time period that persist as the individual ages (Moschis, 2012; Lee et al, 2012; Obal and Kunz, 2013).

In short, emotional, relational and experience-linked variables acquire greater importance as the individual gets older, in contrast to more cognitive evaluations. Furthermore, throughout their lives individuals encounter personal events and circumstances that modify their attitudes and behaviors.

\section{Consequences of the life-course paradigm for the consumer loyalty model}

The life-course paradigm adds a new dimension to the consumer loyalty model because it improves understanding of the evolution of consumer loyalty over time. The life-course paradigm includes the effect of the variable time, which, together with life events and social norm, serve as turning 
points and affect a person's life. This perspective represents flow models explaining transitions between successive stages (Bauer and Auer-Srnka, 2012). Negative news from the financial crisis influences attitude-behavior loyalty consistency because it modifies the social norm. Human capital theory postulates that individuals acquire qualifications, resources, knowledge, and skills (Mathur et al, 2003; Benmoyal-Bouzaglo and Moschis, 2010), influenced by macro-level (e.g. culture) and micro-level (e.g. family) environmental factors (Moschis, 2007).

Following the model in Dick and Basu (1994), negative news stemming from an event of the intensity of the 2008 financial crisis has modified different variables in the consumer loyalty model. For example, the poor perception of the finance industry has generated lower expectations of service and negative word-of-mouth, undermining customers' trust in their banks and altering the emotions related to these institutions. Therefore the relations between the model variables also change, an aspect that the life-course paradigm considers will depend on the age of the consumer.

Therefore, in general terms, in younger consumers and in the initial stages of a relationship, trust has a high cognitive component, whereas in older consumers and advanced phases of a relationship, the emotional component predominates. This evolution is explained by some authors through Socioemotional Selectivity Theory (SST) that suggests that people's motivation changes as they grow older (Carstensen, 2006; Jahn et al, 2012). Adult development involves a shift from expansionist motives, like achievement or identity development, to motives involving security or threat avoidance (Helsonand Soto, 2005). When the future is perceived as limited, people tend to be more present oriented and immediate needs, such as emotional states, become the most salient. The proportion of emotional to non-emotional information recalled from social narratives increases from an earlier age group (50-65) to a successive one (70-83 years) (Jahn et al, 2012). This emotional drift is also justified by three mechanisms that modulate the preferences of older 
consumers and lead them to prefer old brands for affective reasons: nostalgia, declining innovativeness and attachment (Lambert-Pandraud and Laurent, 2010).

The key question is what effect has the irruption of a life circumstance of the magnitude of the 2008 financial crisis on consumer trust? It seems logical to think that the effect will differ according to age. In younger consumers, where the cognitive vision of trust prevails, rational arguments will have a greater impact. In this segment of the population, trust has been eroded with negative news from each bank. In contrast, in older consumers with a longer relationship with banks and where the emotional dimension of trust predominates, negative information will have less effect, as the personal and affective links established with the financial institutions will be paramount. Jahn et al (2012), from the SST view, posits that the elderly are less likely to question items they have known for a long time. Instead of searching for evidence that a favored brand might have trust deficits, older people focus on the positive aspects of a previously chosen option. Unless older people become really dissatisfied with a product, they do not look for alternatives. Laufer, Silvera and Meyer (2006) show that in a trust threatening product harm crisis, older consumers did not blame the company and did not react with reduced purchase.

Dick and Basu (1994) state that emotions act as better predictors of behavior than cognitive evaluations when behavior becomes habitual through repeated past experiences, because it becomes relatively free of cognitive appraisal and within specific domains may be guided by past emotional experiences. In the case of older consumers, given the pre-eminence of past emotional experiences, trust plays a more significant role than it does in younger people. As McAllister (1995) points out, accumulated experience leads to the development of affective trust in consumers which represents a stronger link than the cognitive trust that develops at the start of a relationship in the younger segment. Thus it can be posited that in a financial crisis period trust has more effect on attitudinal loyalty in older consumers because negative news have less impact. 
$\mathrm{H}_{1}$ : The relationship between trust and attitudinal loyalty is stronger in older consumers than in younger consumers.

Negative news from the crisis can influence satisfaction because it can alter subjective norms, service expectations and the emotional state. According to the life-course paradigm, certain bank behaviors in the 2008 crisis created a negative social climate toward the financial system, worsening expectations, consumer perception and reputation and relative beliefs about financial institutions which according to Coping theory and Human capital theory, affected the emotional component of satisfaction. From the theoretical perspective, overall older customer satisfaction, where experience accumulates, is more important than episodic satisfaction, which takes situational events into account. Therefore negative news will have a greater impact on younger consumers, who are more sensitive to episodic satisfaction, and their cognitive evaluation will have a great impact on their future expectations (trust). In contrast, episodic satisfaction is less important for older consumers than for younger ones, and so negative news will have less impact. Furthermore, in the formation of trust and satisfaction in older consumers, other emotional mechanisms intervene like nostalgia and attachment, and therefore during a financial crisis, the relationship between satisfaction and trust will be less important than in the younger segment. Hence:

$\mathrm{H}_{2}$ : The relationship between satisfaction and trust is weaker in older consumers than in younger consumers.

Customer satisfaction is considered a key driver of the long-term relationship between suppliers and buyers (Westbrook and Oliver, 1991). The impact of the financial crisis has made episodic satisfaction particularly relevant, and so the relationship between satisfaction and attitudinal 
loyalty is stronger in younger people than in older consumers. Therefore we posit that satisfaction in older consumers will have less impact on attitudinal loyalty than in the younger segment.

$\mathrm{H}_{3}$ : The relationship between satisfaction and attitudinal loyalty is weaker in older consumers than in younger consumers.

Switching costs have a significant influence on attitudinal loyalty in banking industry (De Matos et al., 2009; El-Manstrly et al, 2011). In the case of older consumers it should be remembered that they base their purchase decisions on accumulated experience and emotions whereas younger people are exposed to a broad range of cognitive influences. Nostalgia, declining innovativeness and attachment strengthen the importance of positive switching costs in older consumers, so that their influence on loyalty will be greater than among younger consumers. Moschis and Nguyen (2008) find that lower fees and discount programs seem to be ineffective in attracting affluent older people to services. In line with Moschis et al (2003), marketers should not use price appeal to mature consumers to create competitive advantage. It can also be posited that positive switching costs will be more significant than negative ones for older people.

$\mathrm{H}_{4}$ : The relationship between positive switching costs and attitudinal loyalty is stronger in older consumers than in younger consumers.

$\mathrm{H}_{5}$ : The relationship between negative switching costs and attitudinal loyalty is weaker in older consumers than the relationship between positive switching costs and attitudinal loyalty.

Trust reduces the perception of risk and increases the feeling of wanting to remain in the relationship, and therefore trust increases positive switching costs (Maicas et al., 2006; El-Manstrly et al. 2011). Older consumers will see this relationship promoted due to the three affective mechanisms that determine their preferences. When people reach a certain point in their life 
where their social network shrinks, a realignment of social relationships takes place (Patterson, 2007). The concept of social support (weak and strong network ties) explains why older consumers satisfy part of their need for a wider social network, or at least social exchange, by engaging in conversation with service personnel.

$\mathrm{H}_{6}$ : The relationship between trust and positive switching costs is stronger in older consumer than in younger people.

However, negative switching costs can be perceived as opportunistic behaviors by suppliers in a position of power (De Matos et al., 2009). Gurjeet et al. (2012) found that for a high switching barrier, Indian bank customers, the satisfaction-loyalty link is weak. Ranaweera and Prabhu (2003) concluded that switching barriers help to retain not only satisfied but also dissatisfied customers. Colgate et al. (2007) noted that switching barriers play a major role in keeping customers tied to their current service provider in various service industries such as banking, insurance and health. Therefore, reductive elements of freedom can adversely affect individual trust. Due to the above three major mechanisms, older consumers have greater emotional inertia due to duration of the relationship and they become less sensitive. We therefore propose:

$\mathrm{H}_{7}$ : The relationship between negative switching costs and trust is weaker in older consumers than in younger consumers.

In the relationship between switching costs and satisfaction, it can also be established that satisfaction will favorably influence positive switching costs, promoting the sensation of wanting to remain in the relationship. Wieringa and Werhoef (2007) found that the decision to switch does not necessarily depend on the perception of switching costs and attractiveness of the alternative. The influence of the mechanisms of nostalgia, declining innovativeness and attachment reduce the influence of satisfaction in older consumers, while the greater importance of episodic satisfaction 
for younger consumers promotes the importance of satisfaction in that segment. Therefore we posit:

$\mathrm{H}_{8}$ : The relationship between satisfaction and positive switching costs is weaker in older consumers than in younger consumers.

Brand image is an important antecedent of satisfaction, trust and loyalty (Fredericks and Salter, 1995; Bigné et al, 2001; Eskildsen et al, 2004; Faullant, Matzler and Füller, 2008). Although few empirical studies analyze how brand preferences vary with age, several studies show a tendency for older consumers to prefer long-established options (Lambert-Pandraud et al, 2005; Anderson and Sharp, 2009; Lambert-Pandraudand Laurent, 2010). Different complementary mechanisms may lead to such results: nostalgia, declining innovativeness and attachment. According to Cole et al (2008), the nostalgia mechanism suggests consumers develop preferences during a critical period, between the ages of 15 and 30 for instance, and keep them for life. An alternative attachment mechanism proposes that over the years consumers can develop an attachment to a brand, even if their first encounter with it occurs at a later age. A habit mechanism proposes that because habits become stronger with age, older adults may be more likely to prefer long-established options. Another explanation relies on a possible age-associated absence or decrease in innovativeness accompanied by a possible inverse relationship between age and willingness to explore new options. Additionally, older adults put more emphasis on affective factors, which could lead them to prefer long-known options.

According to Dick and Basu (1994), older consumers prefer brands with which they have a long direct experience; they come spontaneously to mind, automatically activate feelings of satisfaction and trust and guide their loyalty behavior. Therefore, as consumers age the emotional links with their preferred brands intensify and so it can be posited that brand image is a more significant antecedent of satisfaction, trust and, indirectly, loyalty than in the younger segment. Therefore: 
$\mathrm{H}_{9}$ : The relationship between brand image and satisfaction is stronger in older consumers than in younger consumers.

$\mathrm{H}_{10}$ : The relationship between brand image and trust is stronger in older consumers than in younger consumers.

The final question is whether there is a causal relation between brand image and switching costs. It seems evident that there is, as positive switching costs are barriers to leaving a relationship that make consumers want to remain in the relationship. In addition to objective monetary costs, switching costs may also be psychological in nature, like subjective norms or social rules (Dick and Basu, 1994). Brand image is an important argument in favor of continuing the relationship because it implies an affective link which will also be more relevant for older consumers due to the emotional mechanisms that determine the formation of their preferences.

$\mathrm{H}_{11}$ : The relationship between brand image and positive switching costs is stronger in older consumers than in younger consumers.

\section{Method}

This study focuses on the Spanish banking industry customers. The 2008 financial crisis hit the southern part of the European Union especially hard, and particularly the banks in Spain which in October 2011 received a bailout from the European Union for up to one billion euros. The enormous volume of negative news on this sector has severely eroded citizens' trust in banks since 2008.

The scales used to measure brand image, satisfaction and trust used the items proposed by Martínez et al. (2008), Bloemer and Odekerken-Schroeder (2002) and Ganesan (1994), respectively 
(Table 1). The items for attitudinal loyalty were based on the paper by Caruana (2004), and switching costs were measured using the scales by Burnham et al. (2003) and De Matos et al. (2009). The items of the questionnaire were valued by a 5 point Likert scale where $1=$ Totally Disagree and $5=$ Totally Agree. Also, to ensure the quality of the scales, the original version of the questionnaire, in English, was adapted for banking and translated to Spanish using the inverse translation method (Brislin, 1970).

Table 1. Scales used

Prior to the field work, and following the recommendations of Ye et al. (2007) on questionnaire design, careful attention was paid to the question order and the use of terminology and language that respondents would easily understand, and pretests were also carried out with subjects from the study populations. Care was also taken not to present the constructs in the order set out in our hypotheses (antecedents $\rightarrow$ mediating variables $\rightarrow$ consequences). The questionnaires items were examined by experts from the sphere of banking and pre-tested through 110 personal interviews with users of bank services in February 2011. This procedure helped to improve the wording of some of the questionnaire items, ensuring that the form, layout, sequence difficulty, length of the questionnaires and completion time were appropriate.

The study was carried out by means of personal interviews conducted by independent professional interviewers between March and April 2011. Until that date the Spanish government had undertaken two restructurings of the banks, based on merging savings banks which at the time represented 50\% of bank deposits. In March 2011 Moody's downgraded the long-term debt for 30 Spanish banks and savings banks. To ensure there was no significant interviewer effect in the results, following Hox (1994) and Kish (1962) we used the intraclass correlation coefficient (ICC), with results close to 0.031 , as recommended by the literature for face-to-face surveys (Groves, 2004; Davis et al., 2010; Tortosa et al., 2015). 
The self-completion technique was not used so as to avoid erroneous interpretations of the questions. This technique is frequently associated with greater effects caused by common method bias (Podsakoff et al., 2003; Friedrich et al., 2009; Williams et al., 2010; Fuller et al., 2016). For this reason we used professional interviewers to ensure that the interviews would follow a standard structure, and to guarantee that respondents understood the exact meaning of all the questions.

Finally 634 valid surveys were conducted in Spain (262 in Barcelona, 277 in Madrid and 95 in Valencia) on customers of financial entities. Respondents were selected by means of a random sample of people detected in the bank branches in each of the three cities studied, the three largest cities in Spain. To ensure sample representativeness stratification criteria were established according to locality, sex and age of the respondents. The Spanish population pyramid report was taken as a reference, which is based on 2011 population census data provided by the official Spanish Statistical Office (INE). The composition of the sample therefore reflected the proportionality of the study population.

Common method variance (CMV) is known to inflate or deflate the correlations between constructs if such constructs are measured using the same method and at the same moment in time; there is therefore a possibility that common method bias (Cote and Buckley, 1987; Podsakoff, MacKenzie, Lee and Podsakoff, 2003) may have been introduced. To control for this effect the Harman Single Factor test was performed and was concluded that there was no evidence of common method bias in the data used (Harman, 1960; Podsakoff, et al., 2003; Chang et al, 2010; Craighead et al, 2011, MacKenzie and Podsakoff, 2012)

There has been no clear definition of when someone should be classified older or mature. Most studies on the subject establish this age as starting at 50 or 55 years old (Faranda and Schmidt, 1999; Lancaster and Williams, 2002). In this paper we consider people aged 50 and over as older consumers (Rizal, 2002; Moschis and Nguyen, 2008; Yoon and Powell, 2011). Older age has 
traditionally been considered to coincide with retirement. A prevailing view defines old people as those aged 65 and over regardless of their state of health or professional activity. This classification is too simplistic and it contributes little to the understanding of the aging population as consumers. For this reason other alternatives have emerged such the UK Association of Retired and Older Persons and the Saga Group, which consider those aged 50 and over to be old. Biological and psychological ages need to be differentiated, and older consumers' heterogeneity must be accepted (Rizal, 2002). Older consumers may be old in terms of chronological age, but young in terms of heart and mind, and according to Szmigin and Carrigan (2000) their cognitive ages are about ten to twelve years younger than their chronological ages. Therefore, from a more cognitive position, we consider older consumers as those aged 50 and over (Lewis et al, 2011; Lumme-Sandt, 2011; Yoon and Powell, 2012). Thus on the basis of a biological age scale individuals were classified into two balanced groups. There were 322 interviews with individuals aged up to 49 years old and 312 with individuals aged 50 and over. Each group respected the proportion of ages observed in the Spanish population pyramid. A sampling error of $\pm 3.97 \%$ was assumed for a confidence level of $95.5 \%$.

\section{Analysis and results}

\subsection{Measure reliability and validity}

The data were analyzed using structural equation models by means of multi-group analysis, following recommendations from earlier studies for moderating effects (Hombourg and Giering, 2001). The models were estimated from the matrices of variances and covariances by the maximum likelihood procedure with the EQS 6.1 statistical software application (Bentler, 1995). To validate the scales we carried out a study of their dimensionality, validity and reliability (Table 2).

Table 2. Analysis of scale dimensionality, reliability and validity (Fully standardized solution). 
This analysis also enabled us to refine the scales by eliminating non-significant items. We confirmed that each construct was unidimensional (Gerbing and Anderson, 1988) and dropped any items with weak loadings (less than 0.5). The items that shared the same dimensions were averaged to form composite measures for all variables (Bandalos and Finney, 2001; Landis et al., 2000). The next step was to verify the invariance of the measurement instrument, in order to compare the regression coefficients of each of the two samples (moderator effect). Prior to this comparison, we determined the causal relationships for the whole sample in order to test hypotheses 1 to 11 .

In the first phase of the analysis we focused on studying the psychometric properties of the scales for the whole sample. Confirmatory factor analysis provided three items each for brand image and attitudinal loyalty. Four items are obtained for the satisfaction and trust scales. For switching costs we obtained two dimensions: negative switching costs (with two items) and positive switching costs (with three items). As Table 2 shows, the probability associated with chi-squared is over 0.05 , thus indicating an overall good fit of the scales (Jöreskog and Sörbom, 1996). Convergent validity is demonstrated in two ways. First because the factor loadings are significant and greater than 0.5 (Bagozzi, 1980; Bagozzi and Yi, 1988; Hair et al., 2006) and second because the average variance extracted (AVE) for each of the factors is higher than 0.5 (Fornell and Larcker, 1981). Scale reliability is demonstrated because the composite reliability indices for all the dimensions are above 0.6 (Bagozzi and Yi, 1988).

Table 3 shows the discriminant validity of the constructs considered, which was evaluated through AVE (Fornell and Larcker, 1981). Therefore, a construct must share more variance with its indicators than with other constructs in the model. This occurs when the square root of the AVE between each pair of factors is higher than the estimated correlation between those factors, as occurs here, thereby confirming the scale's discriminant validity.

Table 3. Discriminant validity of the scale. 


\subsection{Hypothesis testing}

Multi-group analysis allows us to verify the fit of the model with the data and the invariance of the factor structure in the groups studied. As recommended by Byrne (2001), this type of analysis must begin with a suitably tested fit in each of the separate samples, since it will be considered the base model with which other more restrictive models will be compared. We focus below on the invariance of the measurement instrument. This analysis is conducted prior to the verification of the differences in the parameters that are common to the study variables between the groups considered (Byrne, 2006; Hair et al., 2006). The first step refers to the model considered individually for each of the samples. As Table 4 shows, separately the model fits well in the two samples, younger $\left(\chi^{2}=607.934 ; d f=130\right)$ and older $\left(\chi^{2}=427.652 ; d f=130\right)$. The second step is the simultaneous estimation of the model in both samples, to verify that the number of factors is the same, that is, they have the same form. Again the model also fits adequately $\left(\chi^{2}=1035.586 ; d f=260\right)$. The third step refers to the equality of the factor loadings in the two groups (metrical invariance). When this restriction is introduced into the model, the model fit is not significantly worse than that of the previous step, as deduced from comparison between the $\chi^{2}$ of steps 2 and $3\left(\Delta \chi^{2}=10.282 ; \Delta d f=19\right.$; $p=0.9456>0.05)$, thereby confirming the invariance of the factor loadings.

Table 4. Invariance measurement test

To test hypotheses 1 to 11, the causal relationships are analyzed for the total sample (Table 5). This approach is adequate because the probability of the chi-squared is higher than $0.05(0.30), \mathrm{NFI}$ $(0.98)$ is close to unity and RMSEA is close to zero (0.01).

Table 5. Summary results of the structural model 
The result of the analysis shows that the majority of the relationships hypothesized in the model are supported for the sample as a whole in the direct and positive relationships between trust and attitudinal loyalty (supporting $H_{1}$ ), between satisfaction and trust (supporting $H_{2}$ ), between satisfaction and attitudinal loyalty (supporting $\mathrm{H}_{3}$ ), between positive switching costs and attitudinal loyalty (supporting $\mathrm{H}_{4}$ ), between trust and positive switching costs (supporting $\mathrm{H}_{6}$ ), between negative switching costs and trust (supporting $\mathrm{H}_{7}$ ), between satisfaction and positive switching costs (supporting $\mathrm{H}_{8}$ ), between brand image and satisfaction (supporting $\mathrm{H}_{9}$ ), between brand image and trust (supporting $\mathrm{H}_{10}$ ) and between brand image and positive switching costs (supporting $\mathrm{H}_{11}$ ).

The effect of negative switching costs on attitudinal loyalty is not significant and so $\mathrm{H}_{5}$ is rejected. Furthermore, this result supports $\mathrm{H}_{4}$ which proposes that the effect of positive switching costson attitudinal loyalty $(0.46)$ is greater than the effect of negative switching costs on attitudinal loyalty (not significant).

Next, the existence of significant differences in the causal relationships is estimated, in order to analyze the moderating effect exerted by age group and thus to complete the confirmation of the hypotheses whose relations have been accepted. Then restrictions are added in order to calculate these significant differences between the parameters estimated, by comparing the $\chi^{2}$ of the restricted structural model with the $\chi^{2}$ of the unrestricted structural model, as shown in Table 6 . The analysis carried out to establish the causal relationships between the variables being studied is adequate because the probability of the chi-squared is higher than $0.05(0.32), \mathrm{NFI}(0.98)$ is close to unity and RMSEA is close to zero (0.01). Thus age group (younger vs. older) in financial services was found to partially moderate the model. Table 6 shows the significant differences between younger and older customers in some of the causal relationships considered in the model.

Table 6. Moderating effects of age in the proposed relationships 
In view of the results it can be said that six hypotheses are confirmed entirely (in both the proposed relationship and in the differences between groups): $\mathrm{H}_{1}, \mathrm{H}_{4}, \mathrm{H}_{6}, \mathrm{H}_{7}, \mathrm{H}_{8}$ and $\mathrm{H}_{11}$. Four hypotheses are partially supported (the moderator effect of age has not been confirmed): $\mathrm{H}_{2}, \mathrm{H}_{3}, \mathrm{H}_{9}$ and $\mathrm{H}_{10}$. Only one hypothesis is completely rejected (in both the proposed relationship and the moderator effect of age): $\mathrm{H}_{5}$.

Figure 2 visually shows the results of global and moderating analysis.

Figure 2. Results of global structural model and group models: younger and older

\section{Discussion}

\subsection{Theoretical implications}

The purpose of this study has been to analyze trust in older consumers during a financial crisis using the life-course paradigm and customer loyalty model, as compared to the behavior of younger consumers. The study makes several contributions. Firstly, it analyzes the role age plays in consumer behavior during a period of financial crisis by comparing younger and older consumers. Secondly, it studies the effects of the deep global financial crisis which began in 2008 on consumer trust, analyzing an exceptional cycle that has not occurred in western economies for decades. Thirdly, it applies the life-course paradigm, which enables the identification of differences between cohorts of age and the most significant variables surrounding trust in different segments in an exceptional period. Fourth, this study underlines the central role of trust for older consumers and the shield it represents against negative news.

The serious financial crisis has affected the banking sector in particular and eroded consumer trust, as the official statistics of some countries reflect (MSI, 2011; Stevenson and Wolfers, 2011; CIS 2013). The context of the financial crisis of 2008 generated a great deal of unfavorable news on the 
financial sector, which led to a very negative social climate with regard to financial institutions. In this context trust plays a central role in attitudinal loyalty among older consumers. The tested model shows that older consumers make decisions linearly, taking fewer variables into account. Thus older consumers' trust only has satisfaction as antecedent and attitudinal loyalty as the only consequence. In contrast, in younger people, brand image, satisfaction and negative switching costs influence trust which in turn, determines positive switching costs and attitudinal loyalty. As posited, trust has a greater effect on attitudinal loyalty among older consumers, due to the predominance of the emotional dimension and the intervention of the three mechanisms that shape their preferences (nostalgia, declining innovativeness and attachment). Accumulated experience and cognitive deficiencies in older consumers leads them to place less trust in external stimuli and rely more on internal factors which makes them less vulnerable to negative news and persuasive campaigns. This finding explains the significantly higher measurements of trust among older consumers.

In a time of financial crisis the attitudinal loyalty of older consumers is mainly determined by trust. Expectations that the bank will continue to satisfy their future needs and the perceived reliability and integrity of the service provider are essential for older consumers to continue the relationship. In a crisis time, negative switching costs (penalties) have no relevance for the attitudinal loyalty of older consumers, confirming that marketers should not use price appeal to mature consumers to create competitive advantage (Moschis et al, 2003). As in younger people, positive switching costs (rewards) generate attitudinal loyalty among older consumers. The difference between the two segments is that the cornerstone of older consumers' attitudinal loyalty is trust, whereas for younger people it is positive switching costs or rewards. Therefore following the life-course paradigm, in times of financial crisis, it appears that positive switching costs become more important for generating attitudinal loyalty in younger consumers; in older people, relative attitude 
toward an entity begins to depend on emotional variables linked to experience, to the detriment of rewards (positive switching costs). Satisfaction appears to be a necessary condition whose importance remains invariable with age. Negative switching costs do not generate attitudinal loyalty at any age. These factors seem to suggest that in a period of serious economic crisis, social network is important (Patterson, 2007), but relations with service personnel is not sufficient to make up for loss of trust among older consumers.

According to Dick and Basu's (1994) integrated conceptual framework of customer loyalty, it can be said that generally, older people have high levels of relative attitude toward the entities they work with, involving scenarios of latent loyalty and genuine loyalty. In contrast, younger people generally have low levels of relative attitude, involving scenarios of absence of loyalty or spurious loyalty.

In contrast to the hypothesis, this study has found that, in a period of crisis, positive switching costs (rewards) are less important for older consumers. Exploring the relations in the model in greater depth shows that in older consumers, the only antecedent of positive switching costs is brand image, and the influence of satisfaction disappears. The negative perception of financial institutions as a result of the crisis spontaneously and automatically causes consumers to have a more negative brand image. It would seem that the poor image projected by banks has reduced the social costs (subjective norms) of the decision to change thereby reducing the influence of satisfaction. This finding seems to be supported by the fact that brand image ceases to generate trust directly among older consumers (although it is maintained indirectly through satisfaction). This aspect is a symptom of the shield that surrounds trust and hinders the effects of negative news and a deteriorated brand image.

Thus while switching costs (rewards) play a very significant role in younger people, their influence is more limited in older consumers. The study has found that negative switching costs (penalties) are 
not relevant for older consumers, but in younger people they generate mistrust and do not influence attitudinal loyalty. It seems that during a financial crisis the strategy of generating negative switching costs (penalties) causes mistrust as younger people see them only as obstacles designed to retain them, associating this strategy with the bad banking practices that have come to light with the financial crisis. Negative switching costs can be perceived as opportunistic behaviors performed by suppliers in a position of power (De Matos et al., 2009). Therefore, reductive elements of freedom or penalties adversely affect individual trust. In contrast, positive switching costs or rewards act as an exit barrier and contribute to attitudinal loyalty=

Satisfaction plays a central role in the generation of consumer trust and attitudinal loyalty. No significant differences between the two segments can be found in contrast to the hypothesis. The influence of negative news on episodic satisfaction does not lead to a greater influence on trust and relative attitude to an entity in younger people. The only difference between the two models refers to the impact of satisfaction on positive switching costs, significant only among younger people, which appears to respond to a consequence of the crisis (episodic satisfaction) and the preeminence of the negative image projected by the banks.

Brand image plays a very relevant role in a crisis time. It is not only a fundamental antecedent of satisfaction; it also generates positive switching costs (significantly higher among older consumers). Negative news from the financial sector influences consumer perception, generating a spontaneous, automatic memory associated with negative attributes due to the influence of the change in subjective norms. In contrast to the hypothesis, brand image does not influence trust in older consumers. The justification may come from the emotional shield which appears to surround the attitudes of older consumers. Older consumers rely more on their experience and their emotions than on information from the surrounding environment. Given the large quantity of negative news, older consumers appear to hide behind an emotional shield full of experiences that 
protects their key variable, trust. In contrast, younger people are cognitively more sensitive and in a crisis time their decisions are complex or at least more multivariate than in older consumers.

\subsection{Managerial implications}

This paper has significant managerial implications. The banks that have based their crisis strategy on generating or maintaining negative switching costs (penalties) have made a mistake. From our point of view, the better strategy is a customer-friendly orientation used by banks that have looked after their brand image with a long-term vision. In a time of crisis, older consumers need to reaffirm their trust in the company and so the service provider must continue to generate cognitive and affective satisfaction. In our opinion, contact staff plays a fundamental role in this aspect, as they are the main generator of satisfaction and trust.

The study draws service companies' attention to the importance of using age as a segmentation criterion. Although this variable is widely used to identify segments, companies should examine how age affects their customers' behavior so as to adapt their strategies to this evolution. While at the contact personnel level this adaptation will be parallel to the evolution of the relationship between two parties, at the strategic level it will probably not be taken into account so much. In light of this, contact personnel mobility policies need to be reconsidered as it seems advisable for these employees to remain in their jobs for as long as possible, building relationships with the customer network over time.

The pillars of trust in older consumers are solid as they are based on mechanisms like nostalgia, declining innovativeness and attachment. Older consumer attitudinal loyalty is more difficult to break because of the conservative nature of their habits and values, but that does not mean that the service company can rest on its laurels thinking that the chain cannot be broken. There is less likelihood of losing an older consumer in a period of crisis than a younger consumer (Lambert- 
Pandraud and Laurent, 2010). Although the economic environment generates a negative state of opinion, older consumers are fairly impermeable to negative news and they are protected behind their emotional and experiential shield which leads them to continue trusting their traditional brands.

Seeing the differences between younger and older consumers, service providers need to adopt a long-term orientation with their customers (relationship marketing), given that in periods of financial crisis older consumers could be an important asset. In this regard, older consumers become a strategic segment for service providers because their loyalty has a solid base. To keep this strategic asset, together with relationship marketing, service providers should also commit to experiential marketing, generating positive experiences for their customers from the beginning.

Banking products, by their very nature, tend to be complex. These services are subject to financial mathematics and rules that are often difficult to explain and complicated for the general public to understand. These difficulties are even more acute where older customers are concerned. However, banks' competitive strategies are often based on complex and rational aspects that the consumer assesses at a cognitive level. In this regard, the results of our study suggest that the evaluation pattern of older customers is essentially affective, based on the satisfactory evaluation of their previous experiences. For this segment, banks should simplify communication about products and base their marketing strategies on more affective, experiential aspects.

In summary, we have seen that older customers, as a whole, do not evaluate the same issues nor in the same way, and as such, represent a customer segment in their own right. Therefore a global services package offered to older customers under the same terms and conditions as to the rest of the population is not the best way to build loyalty among this segment. Banks need to examine in 
greater detail which aspects of their service determine whether an experience is satisfactory, and put forward a specific offer to this particular and growing group of consumers.

\subsection{Limitations and future research opportunities}

Caution must be exercised when extending these conclusions to other service contexts. Moschis (2012) emphasizes the importance of examining older consumers in the context of the time and life circumstances in which they are embedded. However, the peculiarities of the financial crisis in the western countries of the European Union gave rise to a very specific context where the effects have been extreme and there has been a lot of negative news since 2008. It is difficult for this situation to occur in another type of services given the strategic nature of the financial sector.

The sample has a limited geographical scope. Spain is in the European Union where the situation in the financial sector is similar to that in other eurozone countries like Ireland, Greece, Italy, Portugal and Cyprus. Although the crisis in the financial sector has affected all western countries, it has not been as intense as in these countries.

We would also point to a final limitation which is the way the sample has been segmented. The 50 years limit separating older consumers is not an agreed limit. In this regard, we think it would be very interesting to explore the segment of older consumers in greater depth and establish different subsegments. It would also be interesting to adopt the multilevel vision of trust proposed by Guenzi, Johnson and Castaldo (2009), in order to specify more accurately where the erosion of consumer trust has occurred.

Finally, the use of transversal data may be seen as a limitation when drawing causal inferences. Future studies could explore the relationships posited using longitudinal data, thereby testing more clearly the possible differences between economic crisis and boom periods. 


\section{References}

Al-Hawari, M.; Ward, T. and Newby, L. (2009), "The relationship between service quality and retention within the automated and traditional context of retail banking", Journal of Service Management, Vol. 20, No. 4, pp. $455-472$.

Amatulli, C., Guido, G. and Nataraajan, R. (2015). "Luxury purchasing older consumers: exploring inferences about cognitive age, status, and style motivations". Journal of Business Research, Vol. 68, No. 9, pp. 1945-1952.

Anderson, K. and Sharp, B. (2009), "Do growing brands win younger consumers?", International Journal of Market Research, Vol. 52, No. 4, pp. 433-441.

Aurier, P. and N'Goala,G. (2008), "The differing and mediating roles of trust and relationship commitment in service relationship maintenance and development", Journal of the Academy of Marketing Science, Vol. 38, pp. 303-325.

Bagozzi, R. P. and Yi, Y. (1988), "On the evaluation of structural equation models", Journal of the Academy of Marketing Science, Vol. 16 (Spring), pp. 74-94.

Bagozzi, R.P. (1980), "Performance and satisfaction in an Industrial salesforce: An examination of their antecedents and simultaneity", Journal of Marketing, Vol. 44 (Spring), pp. 65-77.

Bailey, A.R., Shaw, G., Alexander, A. and Nell, D. (2010), "Consumer behaviour and the life course: shopper reactions to self-service grocery shops and supermarkets in England c. 1947-75", Environment and Planning A, Vol. 42, No. 6, pp. 1496-1512.

Bandalos, D. L. and Finney, S. J. (2001), "Item parceling issues in structural equation modeling”, in G. A. Marcoulides\& R. E. Schumacker (Eds.), Advanced structural equation modeling: New developments and techniques. Mahwah, NJ: Lawrence Erlbaum Associates, Inc.

Bauer, M and K.J. Auer-Srnka (2012), "The life cycle concept in marketing research", Journal of Historial Research in Marketing, Vol. 4, No. 1, pp. 68-96.

Bell, S.J.; Auh,S. and Smalley,K. (2005), "Customer relationship dynamics: service quality and customer loyalty in the context of varying levels of customer expertise and switching costs", Journal of the Academy of Marketing Science, Vol. 33, No. 2, pp. 169-183.

Benmoyal-Bouzaglo, S. and Moschis, G.P. (2010), "Effects of family structure and socialization on materialism: a life course study in France", Journal of Marketing Theory and Practice, Vol. 18, No. 1, pp. 53-70.

Bentler, P.M. (1995), EQS structural equations program manual, Multivariate Software, Inc., Encino, California.

Bigné, E.J; Sánchez,I. and Sánchez,J. (2001), "Tourism image, evaluation variables and after purchase behaviour: interrelationship", Tourism Management, Vol. 22, pp. 607-616.

Bloemer, J.M.M. and Odekerken-Schroder, G. (2002), "Store satisfaction and store loyalty explained by customer- and store related factors", Journal of Consumer Satisfaction, Dissatisfaction and Complaining Behavior, Vol. 15, No. 1, pp. 68-80.

Botwinick, J. (1978), “Cautiousness in decision”, in Aging and Behavior, Jack Botwinick, ed. New York: Springer, pp. 128141.

Bove, L.L. and Johnson, L.W. (2006), “Customer loyalty to one service worker: should it be discouraged?",International Journal of Research in Marketing, Vol. 23, No. 1, pp. 79-91.

Brislin, R. W. (1970), "Back-translation for cross-cultural research”, Journal of Cross-Cultural Psychology, Vol. 1, No. 3, pp. $185-216$.

Burnham, T.A., Frels, J.K. and Mahajan, V. (2003), "Consumer switching costs: A typology, antecedents, and consequences.", Journal of the Academy of Marketing Science, Vol. 31, No. 2, pp. 109-126.

Byrne, B.M. (2001), Structural equation modeling with AMOS: Basic concepts, applications and programming, Erlbaum, Mahwah, New Jersey. 
Byrne, B.M. (2006), Structural equation modeling with EQS: Basic concepts, applications and programming (2nd edition), Erlbaum, Mahwah, New Jersey.

Carrigan, M. and Szmigin,I. (1999), "Old spice-developing successful relationships with the grey market", Long Range Planning, Vol. 32, pp. 253-262.

Carstersen, L.L. (2006), “The influence of a sense of time on human development”, Science, Vol. 312, pp. 1913-1915.

Caruana, A. (2004), "The impact of switching costs on consumer loyalty: A study among corporate customers of mobile telephony", Journal of Targeting Measurement and Analysis of Marketing, Vol. 12, No. 3, pp. 256-268.

Chandrashekaran, M.; Rotte, K.; Tax,S.S. and Grewal,R. (2007), "Satisfaction strength and customer loyalty", Journal of Marketing Research, Vol. 44, No. 1, pp. 153-163.

Chang, S., Witteloostuijn, A., and Eden, L. (2010),.From the Editors: "Common Method Variance in international business research", Journal of International Business Studies, Vol. 41, pp. 178-184

Chaudhuri, A. and Holbrook,M.B. (2001), "The chain of effects from trust and brand affect to brand performance: the role of brand loyalty", Journal of Marketing, Vol. 65, pp. 81-93.

Chiou, J.S. and Droge,C. (2006), "Service quality, trust, specific asset investment and expertise: direct and indirect effects in a satisfaction-loyalty framework", Journal of the Academy of Marketing Science, Vol. 34, No. 4, pp. 613627.

CIS (2012), "Grado de confianza en las instituciones y grupos sociales: los bancos", available at http://datosbd.cis.es/ciswebconsultas/serieFichaView.htm?idSerie=A102060070\&from=serieList, (accessed5December 2013).

Cole, C.; Laurent, G.; Drole, A.; Ebert, J.; Gutchess, A; Lambert-Pandraud, R.; Mullet, E.; Norton, M.I and Peters, E. (2008), "Decision making and brand choice by older consumers", Marketing Letters, Vol. 19, pp. 355-365.

Colgate, M., Tong, V.T., Lee, C.K. and Farley, J.U. (2007), "Back from the brink, why customers stay", Journal of Service Research, Vol. 9, No. 3, pp. 211-228.

Cote, J.A. and Buckley, R. (1987), "Estimating trait, method, and error variance: generalizing across 70 construct validation studies", Journal of Marketing Research, Vol.24, No. 3, pp. 315-318.

Craighead, C., Ketchen, D., Dunn, K., and Hult, G. (2011), "Addressing Common Method Variance: Guidelines for Survey Research on Information Technology, Operations, and Supply Chain Management", IEEE Transactions on Engineering Management, Vol. 58, No. 3, pp. 578-588

Dagger, T.S. and David,ME. (2012), "Uncovering the real effect of switching costs on the satisfaction-loyalty association", European Journal of Marketing, Vol. 46, No. 3 and 4, pp. 447-468.

Davis, R.E.; Couper, M.P.; Janz, N.K.; Caldwell, C.H. and Resnicow, K. (2010), "Interviewer effects in public health surveys", Health Education Research, Vol. 25, No. 1, pp. 14-26.

De Matos, C.A; Henrique, J.L. and De Rosa, F. (2009): "The different roles of switching costs on the satisfaction-loyalty relationship", International Journal of Bank Marketing, Vol. 27, No. 7, pp. 506-523.

Deb, M. and Chavali,K. (2010), "Significance of trust and loyalty during financial crisis: a study on customer behavior of Indian banks", South Asian Journal of Management, Vol. 17, No. 1, pp. 43-60.

Dick, A.S. and K. Basu (1994), "Customer loyalty: toward an integrated conceptual framework", Journal of the Academy of Marketing Science, Vol. 22, No. 2, pp. 99.113.

Dimitriadis, S.; Kouremenos,A. and Kyrezis,N. (2011), "Trust-based segmentation. Preliminary evidence from technology-enabled bank channels", International Journal of Bank Marketing, Vol. 29, No. 1, pp. 5-31.

Dwyer, F.R.; Schurr,P.H. and Sejo,O. (1987), “Developing buyer-seller relationships”, Journal of Marketing, Vol. 51, No. 2, pp. 11-27. 
El-Manstrly, D.; Paton, T.; Veloutsou,C. and Moutinho,L. (2011), "An empirical investigation of th relative effect of trust and switching costs on service loyalty in the UK retail banking industry", Journal of Financial Services Marketing, Vol. 16, No. 2, pp. 101-110.

Eskildsen, J.; Kristensen, K.; Juhl,J. and Ostergaard,P. (2004), "The drivers of customer satisfaction and loyalty: the case of Denmark 2000-2002", Total Quality Management, Vol. 15, No. 5/6, pp. 859-868.

Estrada, M., Moliner, M.A. and Sánchez, J. (2010). "Attitudes Toward Advertisements Of Older Adults". The International Journal of Aging \& Human, Vol. 70, pp. 213-249.

Estrada, M., Fandos, J.C., Monferrer, D., Segarra, M. and Moliner, M.A. (2014). "La Calidad del Servicio en la Banca Española: el Caso de las Personas Mayores". Revista Portuguesa de Marketing, Vol. 33, pp. 75-91.

Eurostat (2011),Demography report 2010: older, more numerous and diverse europeans, Luxembourg: Publications Office of the European Union. Available at http://epp.eurostat.ec.europa.eu/cache/ITY_OFFPUB/KE-ET-10001/EN/KE-ET-10-001-EN.PDF (accessed 5 December 2013)

Faranda, W.T. and Schmidt, S.L. (1999), "Segmentation and the senior traveller: implications for today's and tomorrow's aging consumer", Journal of Travel and Tourism Marketing, Vol. 8, No. 2, pp. 3-27.

Faullant, R.; Matzler, K., and Füller, J. (2008), "The impact of satisfaction and image on loyalty: the case of Alpine ski resorts", Managing Service Quality, Vol. 18, No. 2, pp. 163-178.

Fornell, C. (1992), “A national customer satisfaction barometer: the swedish experience”, Journal of Marketing, Vol. 56, No. 1, pp. 6-21.

Fornell, C. and Larcker, D. (1981), "Structural equation models with unobservable variables and measurement error", Journal of Marketing Research, Vol. 18, No. 1, pp. 39-50.

Fredericks, J.O. and Slater, J.M. (1995), “Beyond customer satisfaction”, Management Review, may, pp. 29-32.

Friedrich, T. L.; Byrne, C. L. and Mumford, M. D. (2009), "Methodological and theoretical considerations in survey research", The Leadership Quarterly, Vol. 20, pp. 57-60.

Fuller, C.M.; Simmering, M.J.; Atinc, G.; Atinc, Y. and Babin, B.J. (2016), "Common methods variance detection in business research", Journal of Business Research, Vol. 69, pp. 3192-3198.

Ganesan, S. (1994), "Determinants of Long-Term Orientation in Buyer-Seller Relationships", Journal of Marketing, Vol. 58 (abril), pp. 1-19.

Gerbing, D.W. and Anderson, J.C., (1988), "An updated paradigm for scale development incorporating unidimensionality and its assessment", Journal of Marketing Research, Vol. 25, No. 2, pp. 186-192.

Groves, R.M. (2004), "Survey Errors and Survey Costs”, John Wiley \& Sons, Hoboken, NJ.

Guenzi, P.; Johnson, M.D. and Castaldo, S. (2009), "A comprehensive model of customer trust in two retail stores", Journal of Service Management, Vol. 20, No. 3, pp. 290-316.

Gurjeet Kaur, R.D.S. and Mahajan, N (2012), "Exploring customer switching intentions through relationship marketing paradigm", International Journal of Bank Marketing, Vol. 30, No. 4, pp. 280-302.

Hair, J.F. Jr., Black, W.C., Babin, B.J. Anderson, R.E. and Tatham, R.L. (2006), Multivariate data analysis.6th ed., Prentice Hall, New Jersey.

Harman, H. H. (1960), Modern factor analysis, University of Chicago Press, Chicago.

Helson, R. and Soto, C. J. (2005), "Up and down in middle age: monotonic and nonmonotonic changes in roles, status, and personality", Journal of Personality and Social Psychology, Vol. 89, No. 2, pp. 194-204.

Hill, R., Beynon-Davies, P., and Williams, M. (2008). "Older people and internet engagement. Acknowledging social moderators of internet adoption, access and use". Information Technology \& People, Vol. 21, No 3, pp. $244-266$. 
Holbrook, M.B. and Schindler, R.M. (1996), "Market segmentation based on age and attitude toward the past: concepts, methods, and findings concerning nostalgic influences on customer tastes", Journal of Business Research, Vol. 37, pp. 27-39.

Hombourg, C., and Giering, A. (2001), "Personal characteristics as moderators of the relationship between customer satisfaction and loyalty: An empirical analysis", Psychology and Marketing, Vol. 18, No. 1, pp. 43-66.

Hox, J.J. (1994), "Hierarchical regression models for interviewer and respondent effects", Sociological Methods \& Research, Vol.22, No. 3,pp. 300-318.

Jahn, S.; Gaus,H. and Kiessling,T. (2012), "Trust, commitment, and older women: exploring brand attachment differences in the elderly segment", Psychology and Marketing, Vol. 29, No. 6, pp. 445-457.

Jarvis, C.B., Mackenzie, S.B. and Podsakoff, P.M. (2003), “A Critical Review of Construct Indicators and Measurement Model Misspecification in Marketing and Consumer Research", Journal of Consumer Research, Vol. 30, No. 2, pp. 199-218.

Johnson, D. and Grayson,K. (2005), "Cognitive and affective trust in service relationships", Journal of Business Research, Vol. 58, No. 4, pp. 500-507.

Jones, M.A.; Reynolds, K.E.; Mothersbaugh,D.L. and Beatty,S.E. (2007), "The positive and negative effects of switching costs on relational outcomes", Journal of Service Research, Vol. 9, No. 4, pp. 335-355.

Jöreskog,, K.G. and Sörbom, D. (1996). LISREL 8: Structural equation modeling with the SIMPLIS command language, Scientific Software International, Chicago, Illinois.

Kamakura, W.A.; Wedel, M.; De la Rosa,F. and Mazzon,J.A. (2003), "Cross-selling through database marketing: a mixed factor analyzer for data augmentation and prediction", International Journal of Research in Marketing, Vol. 20, No. 1, pp. 45-65.

Kantsperger, R. and Kunz,W.H. (2010), "Consumer trust in service companies: a multiple mediating analysis", Managing Service Quality, Vol. 20, No. 1, pp. 4-25.

Kish, L. (1962), "Studies of interviewer variance for attitudinal variables", Journal of the American Statistical Association, Vol. 57, pp. 92-115.

Lam, S.I.; Shankar,V. and Murthy,M.K.E.B. (2004), "Customer value, satisfaction, loyalty and switching costs: an illustration from a business-to-business service context", Journal of Academy of Marketing Science, Vol. 32, No. 3, pp. 293-311.

Lambert-Pandraud, R. and Laurent,G. (2010), "Why older consumers buy older brands? The role of attachment and decline innovativeness", Journal of Marketing, Vol. 74, july, pp. 104-121.

Lambert-Pandraud, R.; Laurent,R. and Lapersonne,E. (2005), "Repeat purchasing of new automobiles by older consumers: empirical evidence and interpretations", Journal of Marketing, Vol. 69, pp. 97-113.

Lancaster, G. and Williams, I. (2002), "Consumer segmentation in the grey market relative to rehabilitation products", Management Decisions, Vol. 40, No. 4, pp. 393-410.

Landis, R.S., Beal, D.J., and Tesluk, P.E. (2000), "A comparison of approaches to forming composite measures in structural equation models", Organizational Behavioral Research, Vol. 3, pp. 186-207.

Laufer, D.; Silvera,D.H. and Meyer,T. (2006), "The impact of aging on consumer attributions of blame for a product harm crisis", in C. Pechmann\& L. Price (Eds.), Advances in consumer research, Duluth, MN: Association for Consumer Research, pp. 704-705.

Lee, E; Mathur, A.;Fatt,C.K. and Moschis,G.P. (2012), "The timing and context of consumer decisions", Marketing Letters, Vol. 23, pp. 793-805.

Lewis, D.C.; Medvedev, K. and Seponski, D.M. (2011), "Awakening to the desires of older women: Deconstructing ageism within fashion magazines", Journal of Aging Studies, Vol. 25, pp. 101-109.

Lumme-Sandt, K. (2011), "Images of ageing in a 50+ magazine", Journal of Aging Studies, Vol. 25, pp. 45-51. 
MacKenzie, S. B., and Podsakoff, P. M. (2012), "Common Method Bias in Marketing: Causes, Mechanisms, and Procedural Remedies", Journal of Retailing, Vol. 88, No. 4, pp. 542-555.

Maicas, J.P.; Polo, Y. and F.J. Sese (2006), "The impact of customer relationship characteristics on customer switching behavior: differences between switchers and stayers", Managing Service Quality, Vol. 16, No. 6, pp. 556-574.

Marthur, A., Moschis, G. and Lee, E. (2003), "Life events and brand preference changes", Journal of Consumer Behaviour, Vol. 3, No. 2, pp. 129-141.

Martínez, E., Pina, J.M., and Chernatony, L. (2008), "Influencia de la estrategia de extensión de marca en la imagen de marcas globales un análisis aplicado a los mercados inglés y español", Cuadernos de Economía y Dirección de la Empresa, Vol. 36, No. 1, pp. 77-112.

Martínez, E., Polo, Y. and Chernatony, L. (2008), "Effect of brand extension strategies on brand image: A comparative study of the UK and Spanish markets", International Marketing Review, Vol. 25, No. 1, pp. 107-137.

McAllister, D.J. (1995), “Affect and cognition-based trust as foundations for interpersonal cooperation in organizations", Academy of Management Journal, Vol. 38, No. 1, pp. 24-59.

Monferrer-Tirado, D., Estrada-Guillen, M., Fandos-Roig, M., Moliner-Tena, M.A. and Sánchez-Garcia, J. (2016). "Service quality in bank during an economic crisis", International Journal of Bank Marketing, Vol. 34, No 2, pp. 235-259.

Morgan, R.M. and Hunt,S.D. (1994), "The commitment-trust theory of relationship marketing", Journal of Marketing, Vol. 58, pp. 20-38.

Moschis, G.P. (1994), "Consumer behaviour in later life: multidisciplinary contributions and implications for research", Journal of the Academy of Marketing Science, Vol. 22, No. 3, pp. 195-204.

Moschis, G.P. (2007), "Life course perspectives on consumer behaviour", Journal of the Academy of Marketing Science, Vol. 35, No. 2, pp. 295-307.

Moschis, G.P. (2012), "Consumer behavior in later life: current knowledge, issues, and new directions for research", Psychology \& Marketing, Vol. 29, No. 2, pp. 57-75.

Moschis, G.P. and Nguyen,H.V. (2008), "Affluent mature consumers: preference and patronisation for financial services", Journal of Financial Services Marketing, Vol. 13, No. 3, pp. 259-267.

Moschis, G.P., Hosie, P. and Vel, P. (2009), "Effects of family structure and socialization on materialism: a life course study in Malaysia", Journal of Business and Behavioral Sciences, Vol. 21, No. 1, pp. 166-181.

Moschis, G.P.; Bellenger,D.N. and Curasi,C. (2003), "Financial-service preference and patronage motives of older consumers", Journal of Financial Services Marketing, Vol. 7, No. 4, pp. 331-340.

MSI (2011),2012-2014 Research Priorities, Marketing Science Institute. Available at http://www.msi.org/research/msiresearch-priorities/ (accessed 5 December 2013).

Obal, M. and Kunz, W. (2013): "Trust development in e-services: a cohort analysis of Millennials and Baby Boomers", Journal of Service Management, Vol. 24, No. 1, pp. 45-63.

Oliver, R.L. (1999), “Whence customer loyalty?”,Journal of Marketing, Vol. 63, pp. 33-44.

Patterson, P.G. (2007), "Demographic correlates of loyalty in a service context", Journal of Services Marketing, Vol. 21, No. 2, pp. 112-121.

Podsakoff, P.M., MacKenzie, S.B., Lee, J. and Podsakoff, N.P. (2003), "Common method bias in behavioral research: a critical review of the literature and recommended remedies", Journal of Applied Psychology, Vol. 88, No. 5, pp. 879903.

Price, L.; Arnould,E.J. and Curasi,C.F. (2000), “Older consumers' disposition of special possessions”, Journal of Consumer Research, Vol. 27, september, pp. 179-201.

Ramón-Jerónimo, M. A., Peral-Peral, B., and Arenas-Gaitán, J. (2013). "Elderly Persons and Internet Use", Social Science Computer Review, Vol. 31, No 4, pp. 389-403. 
Ranaweera, C. and Prabhu, J. (2003), "The influence of satisfaction, trust and switching barriers on customer retention in a continous purchasing setting", International Journal of Industry Management, Vol. 14, Nu. 4, pp. 374-395.

Rauyruen, P.; Miller,E. and Barrett,N.J. (2007), "Relationship quality as a predictor of B2B customer loyalty", Journal of Business Research, Vol. 60, No. 1, pp. 21-31.

Reisenwitz, T; Iyer, R.; Kuhlmeier,D.B. and Eastman,J.K. (2007), "The elderly's internet usage: an updated look", Journal of Consumer Marketing, Vol. 24, No. 7, pp. 406-418.

Rizal, A. (2002), "The older or ageing consumers in the UK: are they really different?", International Journal of Market Research, Vol. 44, No. 3, pp. 337-360.

Schindler, R.M. and Holbrook,M.B. (2003), "Nostalgia for early experience as a determinant of consumer preferences", Psychology \& Marketing, Vol. 20, No. 4, pp. 275-302.

Stern, B. (1992), "Historical and personal nostalgia in advertisment text: the fin de siecle effect", Journal of Advertising, Vol. 31, december, pp. 11-22.

Stevenson, B. and Wolfers,J. (2011), "Trust in public institutions over the business cycle", American Economic Review: Papers \& Proceedings, Vol. 101, No. 3, pp. 281-287.

Szmigin and Carrigan (2000), "The older consumer as innovator. Does cognitive age hold the key?",Journal of Marketing Management, Vol. 16, pp. 505-527.

Thompson, M.; Maclnnis,D. J. and Park,W. (2005), "The ties that bind: measuring the strength of consumers' emotional attachments to brands", Journal of Consumer Psychology; vol. 15, No. 1, pp. 77-91.

Tong, C.; Wong,S.K.S. and Lui,K.P.H. (2012), "The influences of service personalization, customer satisfaction and switching costs on e-loyalty", International Journal of Economics and Finance, Vol. 4, No. 3, pp. 105-114.

Tortosa, V.; Llorens, J.; Moliner, M.A. and Sánchez, J. (2015), “The influence of internal market orientation on external outcomes", Journal of Service Theory and Practice, Vol. 25, No. 4,pp. 486-523.

Trif, S.M. (2013), "The influence of overall satisfaction and trust on customer loyalty", Management and Marketing, Vol. 8, No. 1, pp. 109-128.

Villarejo-Ramos, Á.F., Rondán-Cataluña, F.J., and Revilla-Camacho, M.A. (2016). "Typology of online shoppers over 55", Innovar, Vol. 26, No 59, pp. 61-72.

Westbrook, R.A. and Oliver,R.L. (1991), "The dimensionality of consumption emotion patterns and consumer satisfaction", Journal of Consumer Research, Vol. 18, No. 1, pp. 84-91.

Wieringa, J.E. and Verhoef, P.C. (2007), "Understanding customer switching behavior in a liberalizing service market", Journal of Service Research, Vol. 10, No. 2, pp. 174-186.

Williams, L.J.; Hartman, N. and Cavazotte, F. (2010), “Method variance and marker variables: A review and comprehensive CFA marker technique", Organizational Research Methods, Vol. 13, pp. 477-514.

Ye, J.; Marinova, D and Singh, J. (2007), "Strategic change implementation and performance loss in the front lines", Journal of Marketing, Vol. 71 (October), pp. 156-171.

Yoon, C.; Cole, C.A. and Lee, M.P. (2009), "Consumer decision making and aging: current knowledge and future directions", Journal of Consumer Psychology, Vol. 19, pp. 2-16.

Yoon, H. and Powell, H. (2012), "Older consumers and celebrity advertising", Ageing \& Society, Vol. 32, pp. 1319.1336.

Yu, Y.T and Dean, A. (2001), "The contribution of emotional satisfaction to customer loyalty", International Journal of Service Industry Management, Vol. 12, No. 3, pp. 234-250.

Zeithaml, V.A.; Berry, L.L. and Parasuraman, A. (1996), "The behavioral consequences of service quality", Journal of Marketing, Vol. 60, Num. 2, pp. 31-46. 